\title{
EFEK MEDIASI MAKNA HIDUP PADA HUBUNGAN ANTARA GRIT DAN KEPUASAN HIDUP PADA MAHASISWA
}

\author{
Krisna Wardhana Djaling \& Debora Eflina Purba ${ }^{1}$ \\ Fakultas Psikologi, Universitas Indonesia, Depok 16424, Indonesia
}

Korespondensi:

le-mail:eflina@ui.ac.id

\begin{abstract}
The current study aimed at examining the relationship between grit and life satisfaction through meaning in life. Data were taken using online survey from university students in Depok city $(N=505)$. Variables were measured using The Grit Scale, Meaning in Life Questionnaire (MLQ), and Satisfaction With Life Scale (SWLS). Data were analyzed using simple mediation model on Hayes PROCESS macro on SPSS program. Results showed that grit was positively and significantly related with life satisfaction and meaning in life, respectively, and meaning in life positively and significantly related with life satisfaction. Lastly, meaning in life partially mediated the relationship between grit and life satisfaction.
\end{abstract}

Article history:

Received 14 January 2019

Received in revised form 26 May 2019

Accepted 5 June 2019

Available online 20 July 2019

\section{Keywords:}

college student:

grit;

life satisfaction;

meaning in life

\begin{abstract}
Abstrak - Penelitian ini dilakukan dengan tujuan mengetahui peran mediasi makna hidup pada hubungan antara grit dengan kepuasan hidup. Data diambil menggunakan survei online pada mahasiswa perguruan tinggi di Kota Depok $(N=505)$. Pengukuran variabel pada penelitian ini dilakukan dengan menggunakan The Grit Scale, Meaning in Life Questionnaire (MLQ), dan Satisfaction With Life Scale (SWLS). Analisis data dilakukan menggunakan model mediasi pada makro PROCESS dari Hayes. Temuan pada penelitian ini menunjukan bahwa grit berpengaruh secara positif pada kepuasan hidup dan makna hidup, kemudian makna hidup berpengaruh secara positif pada kepuasan hidup. Terakhir, makna hidup secara parsial memediasi hubungan grit dan kepuasan hidup.
\end{abstract}

Kata Kunci: grit; kepuasan hidup; mahasiswa; makna hidup 


\section{PENDAHULUAN}

Mahasiswa yang berumur 18 hingga 25 tahun berada pada tahap perkembangan dewasa awal dan memiliki tugas perkembangan yang perlu dicapai dan dipersiapkan, seperti memegang tanggung jawab sebagai bagian dari masyarakat, mulai bekerja mencari pemasukan, serta menemukan kelompok sosial yang sesuai dengan diri (Hurlock, 2009). Namun, Hurlock menyatakan bahwa tidak semua mahasiswa dapat memenuhi tugas perkembangannya dan ini menyebabkan mereka cenderung tidak puas dengan kehidupannya. Penelitian sebelumnya menemukan bahwa mahasiswa yang memiliki kepuasan hidup rendah cenderung mengalami depresi, cemas, dan stres, serta penurunan performa akademik (Mahmoud, Staten, Hall, \& Lennie 2012; Malik, Nordin, Zakaria, \& Sirun, 2013). Selain itu, mahasiswa dengan kepuasan hidup yang rendah juga cenderung keluar dari kampus tanpa menyelesaikan studinya (Behlau, 2010) dan memiliki pemikiran untuk melakukan bunuh diri (You, Song, Wu, Qin, \& Zhou, 2014). Sebaliknya, kepuasan hidup berpengaruh positif pada student engagement (keterlibatan mahasiswa), academic self-efficacy, dan performa akademik mahasiswa (Antaramian, 2017; Rode dkk., 2005) Mengingat pentingnya kepuasan hidup pada mahasiswa, maka penting untuk mempelajari faktor-faktor yang menyebabkan kepuasan hidup mahasiswa menjadi tinggi atau rendah.

Kepuasan hidup didefinisikan sebagai evaluasi menyeluruh dari kualitas hidup seseorang yang bergantung pada kriteria yang telah ditetapkan sendiri, serta tidak hanya mencakup kriteria spesifik, seperti kesehatan, karier, atau keluarga saja (Shin \& Johnson, 1978; Yang \& Srinivasan, 2016). Kepuasan hidup merupakan salah satu komponen dari subjective well-being (Diener, Emmons, Larsen, \& Griffin, 1985) yang didefinisikan sebagai evaluasi individu terhadap hidupnya sendiri berdasarkan unsur kognitif dan afektif (Diener dkk., 1985). Pavot dan Diener (1993) menyebutkan tiga komponen subjective well-being, yaitu afek positif, afek negatif, serta kepuasan hidup. Beberapa penelitian menggabungkan tiga aspek tersebut menjadi skor total subjective wellbeing (Datu, Valdez, King, 2016; Herwibowo, 2010). Namun, penelitian lainnya mengukur aspek dari subjective well-being secara terpisah (Caner, 2015; Niramaya, 2017) dan berfokus hanya pada kepuasan hidup yang merujuk pada evaluasi secara keseluruhan mengenai hidup (Diener, Scollon, \& Lucas, 2009).

Terdapat berbagai faktor yang memengaruhi kepuasan hidup. Diener, Suh, Lucas, dan Smith (1999) menemukan bahwa status ekonomi atau tingkat pendapatan, pekerjaan, status perkawinan, peristiwa atau pengalaman penting dalam hidup, tingkat adaptasi, religiositas, jenis kelamin, tingkat 
pendidikan, serta inteligensi memengaruhi kepuasan hidup. Sedangkan, faktor-faktor lain yang juga memengaruhi kepuasan hidup berkaitan dengan faktor psikologis, seperti self-esteem (Lucas, Diener, \& Suh, 1996), tipe kepribadian Big-Five (selain agreeableness) (Suldo, Minch, \& Hearon, 2014), mood atau suasana hati (Pavot \& Diener, 1993), meaning in life (makna hidup) (Doğan, Sapmaz, Tel, Sapmaz, \& Temizel, 2012; Ho, Cheung, \& Cheung, 2010; Pan, Wong, Joubert, \& Chan, 2008; Steger, Frazier, Oishi, \& Kaler, 2006), serta grit (Akbağ \& Ümmet, 2017; Jin \& Kim, 2017; Li, Fang, Wang, Sun, \& Cheng, 2018; Singh \& Jha, 2008).

Dari tinjauan literatur di atas, grit cukup banyak diteliti sebagai prediktor dalam kepuasan hidup beberapa tahun belakangan. Grit pertama kali didefinisikan sebagai ketekunan (perseverance) dan semangat (passion) dalam mencapai suatu tujuan jangka panjang (Duckworth, Peterson, Matthews, \& Kelly, 2007). Terdapat dua dimensi dari konstruk ini, yaitu perseverance of effort (ketekunan untuk menyelesaikan suatu tujuan, bahkan dengan adanya berbagai rintangan atau halangan) dan consistency of interests (tetap berkomitmen pada minatnya yang akan mengarahkan pada tercapainya suatu tujuan). Setiap individu memiliki derajat grit yang berbeda-beda karena grit merupakan bagian dari kepribadian individu yang menentukan bagaimana individu berinteraksi dalam lingkungan yang beragam (Duckworth \& Quinn, 2009). Grit merupakan prediktor positif terhadap hasil performa akademik, performa kerja, dan work engagement (keterlibatan kerja) (Duckworth dkk., 2007; Suzuki, Tamesue, Asahi, \& Ishikawa, 2015). Selain itu, pada siswa sekolah, grit memengaruhi hubungan interpersonal antar teman, masalah akademik, serta sikap positif mengenai sekolah dan gurunya (Borton \& Grelle, 2013). Kemudian, grit dapat memprediksi faktor psikologis lainnya, seperti tingkat afek positif (Hill, Burrow, \& Bronk, 2016), psychological well-being (kesejahteraan psikologis) (Salles, Cohen, \& Mueller, 2014), makna hidup (Datu, King, Valdez, \& Eala, 2018; Kleiman, Adams, Kashdan, \& Rishkind, 2013), serta kepuasan hidup (Singh \& Jha, 2008; Akbağ \& Ümmet, 2017; Jin \& Kim, 2017; Li dkk., 2018).

Akbağ dan Ümmet (2017) yang meneliti sampel dewasa muda di Turki dan menemukan bahwa grit merupakan prediktor yang signifikan terhadap kepuasan hidup. Jin dan Kim (2017) juga menemukan hal yang serupa pada sampel dewasa muda di negara Korea. Pada populasi karyawan, Li dkk. (2018) menemukan bahwa grit adalah prediktor yang signifikan terhadap kepuasan hidup di negara China. Kemudian, Singh dan Jha (2008) yang melakukan penelitian pada sampel mahasiswa di negara India menemukan bahwa grit memengaruhi kepuasan hidup secara positif. Hasil dari tinjauan literatur tersebut menunjukan bahwa grit merupakan faktor dari kepuasan hidup yang konsisten secara lintas budaya. Namun, grit masih jarang diteliti pada sampel mahasiswa. Oleh 
karena itu, penelitian ini berfokus pada grit sebagai prediktor kepuasan hidup pada populasi mahasiswa di Indonesia.

Dari berbagai penelitian tentang hubungan antara grit dan kepuasan hidup di atas, peneliti menemukan bahwa hubungan antara grit dan kepuasan hidup bersifat tidak langsung. Jin dan Kim (2017) menemukan bahwa autonomy needs (kebutuhan otonomi) dan competence needs (kebutuhan kompetensi) berperan sebagai mediator yang signifikan dalam menjelaskan hubungan grit dan kepuasan hidup pada populasi dewasa muda. Kemudian, Li dkk. (2018) mencoba melihat hubungan antara grit dan kepuasan hidup dengan self-efficacy, self-control, self-esteem, serta selfconsciousness sebagai mediator pada populasi pekerja. Namun, hanya self-esteem yang memediasi hubungan tersebut secara signifikan. Penelitian yang masih terbatas akan faktor-faktor yang menjadi perantara dalam hubungan grit dan kepuasan hidup mendorong peneliti untuk meneliti hubungan tersebut lebih lanjut.

Dalam penelitian ini, peneliti berpendapat bahwa makna hidup merupakan variabel yang dapat memediasi hubungan antara grit dengan kepuasan hidup karena individu dengan grit yang tinggi akan tekun dan konsisten dengan minatnya pada tujuan jangka panjang, sehingga membuat mereka sadar akan makna hidup yang dirasakan, kemudian meningkatkan kepuasan hidup mereka. Makna hidup didefinisikan oleh Steger dkk. (2006) sebagai pemahaman dan perasaan individu akan pentingnya keberadaan atau eksistensi dirinya dalam hidup. Steger dkk. selanjutnya menjelaskan dua dimensi makna hidup, yaitu presence of meaning (kesadaran bahwa suatu hidup memiliki makna) dan search for meaning (dorongan untuk mencari makna hidup). Individu dapat memperoleh makna hidup ketika mereka sudah merasa bahwa dirinya memiliki tujuan dan nilai yang jelas, meyakini bahwa dirinya dapat menghadapi berbagai tantangan hidup, dan merasa bahwa dirinya bermakna (Baumeister, 1991).

Makna hidup memengaruhi kepuasan hidup secara positif dan signifikan (Doğan dkk., 2012; Ho dkk., 2010; Pan dkk., 2008; Steger dkk., 2006). Selain itu, makna hidup juga ditemukan dapat menurunkan kecenderungan individu mengalami masalah kecemasan, depresi, ketidakmampuan dalam menyesuaikan diri secara sosial, dan pengasingan diri (Ho dkk., 2010). Makna hidup juga ditemukan dapat memberikan pengaruh terhadap berkurangnya pemikiran untuk melakukan tindakan bunuh diri (Kleiman, Adams, Kashdan, \& Rishkind, 2013). Penemuan ini menjelaskan bahwa makna hidup diperlukan dalam menilai aspek kehidupan terkait diri sendiri, pencapaian, relasi, pekerjaan, dan kesehatannya sehingga hidup dapat terasa lebih memuaskan. Berdasarkan hasil penelitian ini, peneliti berpendapat bahwa makna hidup merupakan faktor kepuasan hidup 
yang proksimal dibandingkan dengan grit. Individu dengan makna hidup yang tinggi merasakan dirinya mampu menghadapi tantangan hidup karena memiliki pemahaman yang baik tentang dirinya sendiri, Hal ini akan berpengaruh pada peningkatan kepuasan hidupnya.

Berdasarkan penjelasan di atas, grit memengaruhi kepuasan hidup melalui makna hidup. Hubungan antara ketiga variabel tersebut dapat dijelaskan dengan teori kebutuhan akan makna hidup dari Baumeister (1991) yang menyatakan bahwa untuk mencapai kepuasan hidup yang tinggi, dibutuhkan makna hidup yang dapat dicapai ketika seseorang memiliki tujuan hidup yang jelas dan terarah, dan aktivitas yang dilakukannya berhubungan dengan tujuan yang ingin dicapai di masa depan. Seseorang yang memiliki grit tinggi digambarkan sebagai orang yang memiliki tujuan dan konsisten pada minatnya, sehingga perilaku sehari-hari yang ditunjukkan sesuai dengan tujuannya. Semakin banyak usaha yang dikerahkan untuk mencapai tujuannya, semakin dekat dia pada tujuan tersebut. Hal ini kemudian membuatnya semakin mampu memaknai hidup dan pada akhirnya semakin merasa puas pada hidupnya. Sesuai dengan teori di atas, peneliti berargumentasi bahwa hubungan antara grit dengan kepuasan hidup dimediasi oleh makna hidup.

Sepanjang pengetahuan peneliti, belum ada penelitian yang meneliti pola hubungan grit, makna hidup, dan kepuasan hidup. Akan tetapi, Datu, King, Valdez, dan Eala (2018) telah menemukan peran yang signifikan dari makna hidup pada hubungan antara grit dan tingkat depresi. Berbeda dengan penelitian Datu dkk. (2018) yang meneliti siswa SMA dan variabel depresi, penelitian ini berfokus pada populasi mahasiswa dan variabel kepuasan hidup yang merupakan salah satu penyebab rendahnya tingkat depresi. Mahasiswa memiliki tuntutan dan lingkungan belajar yang berbeda dengan siswa SMA atau SMK, di mana tujuan karier mahasiswa lebih terfokus dibandingkan dengan siswa SMA (Hadijah, 2017). Selain itu, kepuasan hidup merupakan variabel well-being yang positif dan berfokus pada penilaian keseluruhan terhadap hidupnya.

\section{METODE}

\section{Partisipan}

Populasi dalam penelitian ini adalah mahasiswa dari perguruan tinggi di Kota Depok dengan rentang usia 17-25 tahun. Papalia, Feldman, dan Martorell (2015) menyatakan bahwa dewasa muda adalah seseorang yang berada pada rentang usia antara 19 hingga 28 tahun. Sampel penelitian ini sebanyak 505 mahasiswa. Rata-rata usia sampel penelitian adalah $19.99(S D=1.138)$. Usia 19-20 tahun merupakan proporsi tertinggi, yaitu berjumlah 282 orang (55.8\%). Kemudian, kelompok 
perempuan lebih banyak dibandingkan kelompok laki-laki, yaitu 351 orang (69.5\%), sementara laki-laki hanya berjumlah 144 orang (28.5\%), dan sisanya (10 orang) memilih untuk tidak menjawab. Mayoritas dari partisipan sedang menjalankan perkuliahan di semester 5 atau 6, yaitu sebanyak 201 orang $(39.8 \%)$.

\section{Desain}

Desain penelitian ini adalah korelasional dengan menggunakan survei online. Variabel prediktor adalah grit, variabel mediator adalah makna hidup, dan variabel outcome adalah kepuasan hidup. Data pada variabel prediktor, mediator, dan outcome diperoleh dengan cara self-report, di mana mahasiswa diminta untuk menilai dirinya sendiri pada setiap variabel pada satu waktu.

\section{Prosedur}

Survei dilakukan secara online dengan cara menyebarkan tautan ke Google Form yang telah disediakan oleh peneliti di group WhatsApp mahasiswa, di mana tautan tersebut diminta untuk disebarkan kepada mahasiswa lain secara snowball. Untuk memastikan bahwa partisipan penelitian memahami hak dan kewajibannya dalam penelitiannya, peneliti menjelaskan bahwa penelitian bersifat sukarela, sehingga partisipan dapat mengundurkan diri kapan saja. Data yang diperoleh dari survei bersifat rahasia dan hanya digunakan untuk kepentingan penelitian. Partisipan yang mengisi kuesioner ini diberikan reward berupa voucher GOPAY sejumlah Rp 25.000,00 yang diundi untuk 30 partisipan terpilih.

\section{Teknik Analisis}

Analisis pertama yang dilakukan peneliti adalah analisis deskriptif untuk melihat karakteristik dan persebaran partisipan berdasarkan data demografis. Rata-rata, frekuensi, serta persentase data demografis partisipan merupakan hal yang dianalisis pada uji deskriptif. Analisis selanjutnya yaitu pengujian hipotesis. Pengujian hipotesis dilakukan dengan melakukan model mediasi dari Hayes (2013) melalui program makro PROCESS versi 3.1 yang dipasangkan pada perangkat lunak SPSS. Melalui PROCESS, peneliti dapat melihat signifikansi efek tidak langsung dari variabel mediator. Variabel-variabel yang diujikan, yaitu hubungan antar variabel dan peran mediasi makna hidup pada hubungan antara grit dengan kepuasan hidup. 


\section{Alat Ukur}

Alat ukur yang digunakan untuk mengukur grit adalah The Grit Scale yang dikembangkan oleh Duckworth dkk. (2007). Alat ukur ini berjumlah 12 butir dan terbagi menjadi dua aspek, yaitu perseverance of effort dan consistency of interest. Skala yang digunakan adalah skala Likert dengan rentang 1-5 (Sangat Sesuai hingga Sangat Tidak Sesuai). Peneliti menggunakan alat ukur ini yang telah melalui proses back translation. Hasil uji coba alat ukur ini pada mahasiswa ditemukan cukup reliabel dengan koefisien sebesar .737 menggunakan Cronbach's Alpha setelah menghilangkan 2 butir grit pada dimensi perseverance of effort karena memiliki koefisien korelasi butir-total yang cukup rendah, yaitu .098 untuk butir 11 dan .073 untuk butir 12. Setelah dihapus, butir dalam The Grit Scale memiliki rentang koefisien korelasi butir-total sebesar .309-.495. Contoh butir dari alat ukur The Grit Scale yang telah diadaptasi pada aspek perseverance of effort, yaitu 'Saya menyelesaikan segala sesuatu yang telah saya mulai' dan 'Masalah tidak membuat semangat saya turun.' Kemudian, pada aspek consistency of interest, yaitu 'Saya sering menetapkan sebuah tujuan, tetapi di kemudian hari memilih untuk membuat tujuan baru' dan 'Ide dan kesempatan kerja baru kadang-kadang membuat saya dapat melupakan ide dan pekerjaan yang sedang berjalan'. Seluruh butir dari consistency of interest merupakan butir unfavorable.

Alat ukur yang digunakan untuk mengukur makna hidup adalah Meaning in Life Questionnaire (MLQ) yang dikembangkan oleh Steger, Frazier, Oishi, dan Kaler (2006). Alat ukur ini mengukur dua aspek dari makna hidup, yaitu searching for meaning dan presence of meaning. Setiap aspek diwakilkan oleh masing-masing lima butir dan setiap butir diberikan respon dengan skala Likert dari rentang 1-7 (Sangat Tidak Sesuai hingga Sangat Sesuai) (Steger dkk., 2006). Hasil uji reliabilitas alat ukur ini cukup reliabel dengan koefisien sebesar .841. Butir dalam alat ukur MLQ memiliki rentang korelasi butir-total sebesar .410-.646. Contoh butir dari alat ukur MLQ yang telah diadaptasi Niramaya (2017) pada aspek searching for meaning adalah 'Saya mencari sesuatu yang membuat hidup saya terasa bermakna' dan 'Saya selalu mencari sesuatu yang membuat hidup saya terasa berarti.' Kemudian, pada aspek presence of makna hidup, yaitu 'Saya telah menemukan tujuan hidup yang memuaskan' dan 'Saya menyadari dengan baik apa yang membuat hidup saya bermakna.' Terdapat satu butir yang merupakan butir unfavorable, yaitu 'Hidup saya tidak memiliki tujuan yang jelas.'

Untuk mengukur kepuasan hidup, peneliti mengambil lima butir yang khusus mengukur kepuasan hidup pada alat ukur Satisfaction With Life Scale (SWLS) yang disusun oleh Diener dkk. (1985). Alat ukur ini mengukur kepuasan hidup secara keseluruhan dan berupa self-report. Terdapat 
skala Likert dengan rentang 1-7 (Sangat Tidak Sesuai hingga Sangat Sesuai). Contoh butirnya, yaitu 'Saya puas dengan hidup saya' dan 'Bila saya dapat mengulang hidup saya, saya tidak akan mengubah apapun.' Alat ukur ini didapatkan dari penelitian sebelumnya yang telah diadaptasi ke dalam bahasa Indonesia oleh Niramaya (2017). Skor reliabilitas alat ukur tersebut sebesar .806 (Cronbach's Alpha). Hal ini menandakan bahwa alat ukur tersebut reliabel untuk mengukur kepuasan hidup karena skor reliabilitas di atas .7 (Kaplan \& Saccuzzo, 2001). Kemudian, rentang koefisian korelasi butir-total pada alat ukur SWLS adalah .435-.699.

Terdapat tiga variabel demografis yang dikontrol sebagai kovariat pada penelitian ini, yaitu usia, jenis kelamin, dan tingkatan semester. Usia ditemukan memengaruhi grit, di mana semakin meningkat usia individu, semakin tinggi pula grit yang dimiliki (Duckworth dkk., 2007). Diener dkk. (1999) menemukan jenis kelamin dapat memengaruhi kepuasan hidup, di mana kepuasan hidup pada laki-laki sedikit lebih tinggi dibandingkan perempuan. Tingkatan semester dimasukan ke dalam variabel yang dikontrol karena perbedaan adaptasi pada mahasiswa semester awal dengan mahasiswa semester akhir. Adaptasi terhadap suatu kejadian merupakan faktor yang memengaruhi kepuasan hidup karena Diener dkk. (1999) menyebutkan bahwa manusia melakukan penyesuaian terhadap lingkungan sekitarnya.

\section{ANALISIS DAN HASIL}

Tabel 1 menunjukkan rata-rata, deviasi standar, dan korelasi antar variabel penelitian. Pengujian korelasi menggunakan Pearson Correlation.

Tabel 1.

Rata-rata, Standar Deviasi, dan Korelasi Antar Variabel

\begin{tabular}{lccccccc}
\hline \multicolumn{1}{c}{ Variabel } & $\boldsymbol{M}$ & $\boldsymbol{S D}$ & $\mathbf{1}$ & $\mathbf{2}$ & $\mathbf{3}$ & $\mathbf{4}$ & $\mathbf{5}$ \\
\hline 1. Usia & 19.99 & 1.14 & 1 & & & & \\
2. Jenis Kelamin & NA & NA & .02 & 1 & & & \\
3. Tingkatan Semester & NA & NA & $.77^{* * *}$ & .08 & 1 & & \\
4. Grit & 3.22 & .56 & .03 & .03 & -.02 & 1 & .01 \\
5. Makna Hidup & 5.33 & .88 & .04 & -.08 & .01 & $.43^{* * *}$ & 1 \\
6. Kepuasan Hidup & 4.30 & 1.13 & .01 & -.06 & .01 & $.41^{* * *}$ & $.43^{* * *}$ \\
\hline
\end{tabular}

Keterangan: $\boldsymbol{N}=505 ; \boldsymbol{N A}=$ Not applicable; Usia diukur dalam tahun; Tingkatan semester diukur dalam periode semester saat ini; Jenis kelamin menggunakan dummy-code $\left(1=\right.$ Laki-laki, 2 = Perempuan). ${ }^{* * *} p<.001 ; * * p<.01 ;{ }^{*} p$ $<.05$ 
Dari tabel di atas, ketiga variabel demografis tersebut tidak memiliki hubungan yang signifikan dengan variabel penelitian. Grit berhubungan positif dan signifikan dengan makna hidup $(r=.43 ; p<.001)$. Hal ini berarti individu yang memiliki tingkat grit yang tinggi cenderung memiliki makna hidup yang tinggi juga. Grit juga berhubungan positif dan signifikan dengan kepuasan hidup $(r=.41 ; p<.001)$. Hal ini berarti individu yang memiliki tingkat grit yang tinggi cenderung memiliki kepuasan hidup yang tinggi juga. Kemudian, makna hidup berhubungan positif dan signifikan dengan kepuasan hidup $(r=.43 ; p<.001)$. Hal ini berarti individu yang memiliki makna hidup yang tinggi cenderung memiliki kepuasan hidup yang tinggi.

Tabel 2.

Efek Mediasi dari Makna Hidup pada Hubungan Grit dengan Kepuasan Hidup

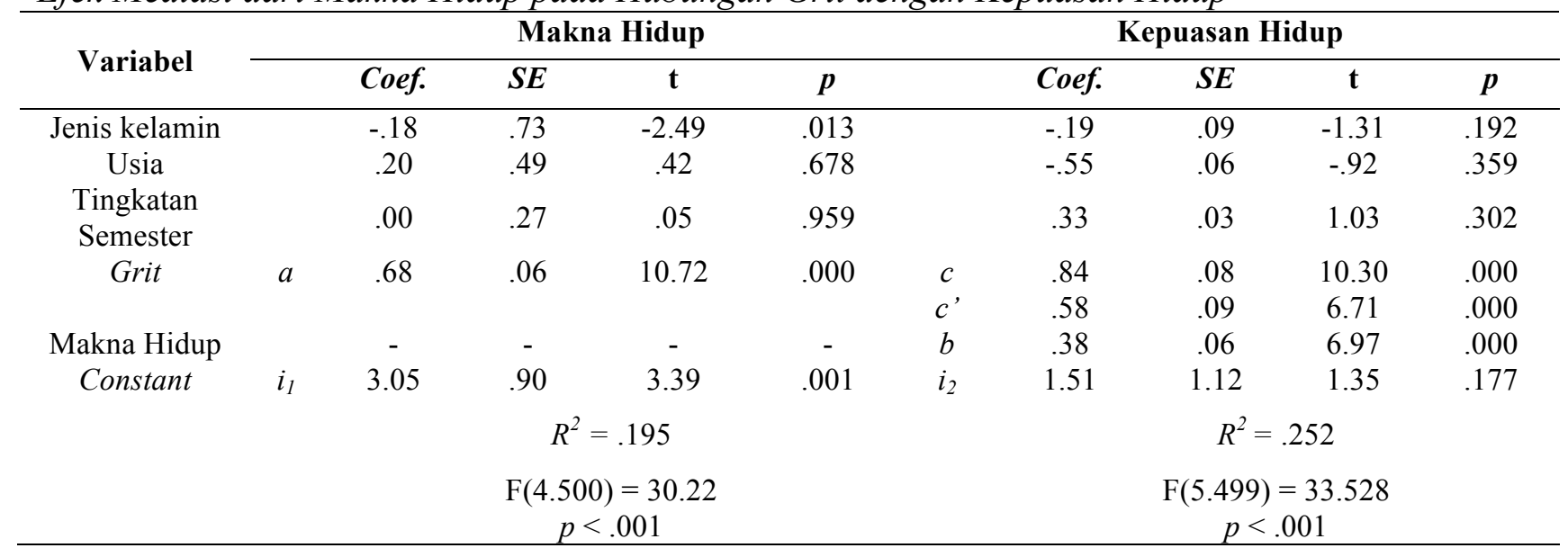

Keterangan: $\boldsymbol{N}=505 ;$ Indirect effect coef. $=.26 ;$ BootSE $=.05 ;$ BootLLCI $=.17 ;$ BootULCI $=.36 ; \boldsymbol{a}=$ jalur dari grit menuju makna hidup; $\boldsymbol{b}=$ jalur dari makna hidup menuju kepuasan hidup; $\boldsymbol{c}=$ efek total dari grit pada kepuasan hidup sebelum makna hidup dimasukan dalam model; $c^{\prime}$ = efek langsung (direct effect) dari grit pada kepuasan hidup setelah makna hidup dimasukan dalam model; $\boldsymbol{i}_{\boldsymbol{1}}$ dan $\boldsymbol{i}_{\boldsymbol{2}}=$ koefisien konstan pada makna hidup dan kepuasan hidup

Berdasarkan Tabel 2, dapat dilihat bahwa makna hidup secara signifikan memediasi hubungan antara grit dengan kepuasan hidup. Efek total dari grit pada kepuasan hidup adalah positif dan signifikan $(c=.84 ; t(505)=10.05 ; S E=.08 ; p<.001)$. Hasil ini menunjukan bahwa hasil penelitian mendukung hipotesis pertama yang menyatakan bahwa terdapat pengaruh yang signifikan dari grit pada kepuasan hidup.

Pengaruh grit pada makna hidup juga ditemukan secara positif dan signifikan $(a=.66 ; t(505)$ $=10.30 ; S E=.06 ; p<.001)$. Hipotesis kedua yang menyatakan bahwa terdapat pengaruh yang signifikan dari grit pada makna hidup didukung oleh data. Dengan kata lain, individu yang memiliki konsistensi minat dan ketekunan untuk mencapai tujuan jangka panjang cenderung memiliki makna hidup yang baik. 
Pengaruh dari makna hidup terhadap kepuasan hidup juga ditemukan berhubungan secara signifikan $(b=.38 ; t(505)=6.94 ; S E=.06 ; p<.001)$, dengan kata lain hipotesis ketiga didukung oleh data. Hal ini menunjukkan bahwa semakin baik individu memaknai hidupnya, maka semakin tinggi kepuasan hidupnya.

Tabel 2 menunjukkan terdapat efek tidak langsung yang signifikan dari grit pada kepuasan hidup melalui makna hidup (indirect effect $=.26$; BootSE $=.05 ; C I[.17-.36]$ ). Dengan demikian, hipotesis keempat yang menyatakan bahwa terdapat peran mediator oleh makna hidup pada hubungan antara grit dan kepuasan hidup didukung oleh data. Akan tetapi, karena pengaruh grit pada kepuasan hidup tetap signifikan, meskipun makna hidup telah dimasukkan ke dalam mode penelitian $\left(c^{\prime}=.58 ; S E=.09, t(505)=6.65 ; p<.001\right)$, dapat disimpulkan bahwa makna hidup memiliki efek mediasi parsial pada hubungan antara grit dan kepuasan hidup. Maka, dapat dijelaskan bahwa semakin tinggi grit pada seorang mahasiswa, semakin tinggi pula dia menilai makna hidupnya yang kemudian membuat kepuasan hidup yang dirasakan semakin tinggi.

\section{DISKUSI}

Penelitian ini bertujuan untuk melihat peran mediasi makna hidup pada hubungan antara grit dan kepuasan hidup. Hasil penelitian menunjukkan bahwa terdapat efek mediasi parsial yang signifikan dari makna hidup pada hubungan antara grit dan kepuasan hidup. Kemudian, hasil ini juga menunjukan bahwa ketekunan dan konsistensi pada tujuan jangka panjang memengaruhi makna hidup yang dirasakan yang pada akhirnya meningkatkan kepuasan hidup mahasiswa.

Grit ditemukan secara signifikan berpengaruh positif pada kepuasan hidup, sehingga mendukung temuan-temuan sebelumnya, baik pada populasi mahasiswa, pekerja, ataupun pada dewasa muda (Akbağ \& Ümmet, 2017; Jin \& Kim, 2017; Li dkk., 2018; Singh \& Jha, 2008). Mahasiswa yang memiliki konsistensi minat dan ketekunan akan tujuan jangka panjang mau bekerja keras mencapai tujuan.

Hasil penelitian ini juga sejalan dengan temuan pada penelitian Datu dkk. (2018) dan Kleiman dkk. (2013), yaitu grit berpengaruh secara positif pada makna hidup secara signifikan. Seseorang yang tekun dan konsisten pada tujuan jangka panjang akan memengaruhi keberadaan dan dorongan untuk mencari makna hidupnya. Semakin dekat mereka dengan tujuan tersebut, semakin terpenuhi pula kebutuhan akan makna hidup mereka. Pengaruh dari makna hidup pada kepuasan hidup juga ditemukan secara positif signifikan, sehingga temuan ini mendukung penelitian- 
penelitian sebelumnya (Doğan dkk., 2012; Ho dkk., 2010; Pan dkk., 2008; Steger dkk., 2006). Hal ini menunjukkan bahwa semakin baik makna hidup mahasiswa, semakin puas mereka pada hidupnya.

Terakhir, peneliti menemukan signifikansi dari peran makna hidup sebagai mediator dalam hubungan antara grit dengan kepuasan hidup. Sesuai dengan teori kebutuhan makna hidup Baumeister, mahasiswa yang memiliki konsistensi minat dan ketekunan pada tujuan jangka panjang yang baik, maka kebutuhan akan makna hidupnya semakin terpenuhi, yang kemudian merasakan kepuasan hidup yang lebih tinggi. Hasil ini penelitian ini membuktikan teori tersebut.

Penelitian ini mengacu pada penelitian Datu dkk. (2018) terkait peran makna hidup dalam hubungan grit dengan tingkat depresi. Hasil penelitian tesebut menyatakan bahwa terdapat peran mediasi dari makna hidup dari hubungan negatif antara grit dengan tingkat depresi pada populasi murid SMA. Berdasarkan hasil itu, penelitian ini dilakukan untuk mengembangkan temuan sebelumnya dengan menguji pola hubungan yang sama dengan mengubah variabel depresi menjadi variabel kepuasan hidup. Mahmoud dkk. (2012) menyebutkan bahwa individu dengan tingkat kepuasan hidup yang tinggi cenderung memiliki tingkat depresi yang rendah.

Namun, terdapat beberapa keterbatasan dalam penelitian ini. Pertama, studi ini bergantung pada self-report pada seluruh variabel penelitian. Hal tersebut dapat menimbulkan potensi common method bias yang umumnya merupakan masalah yang terjadi karena variabel diukur dengan cara yang sama (Podsakoff, MacKenzie, Lee, \& Podsakof, 2003). Penelitian selanjutnya dapat menggunakan pendekatan lain yang tidak bergantung pada diri dalam mengukur grit, misalnya penilaian antar teman atau penilaian dari dosen atau mentor. Kemudian, mengingat desain penelitian ini adalah korelasional, hubungan kausal antara variabel grit, makna hidup, serta kepuasan hidup tidak dapat dipastikan. Oleh karena itu, penelitian selanjutnya disarankan untuk menggunakan desain longitudinal dengan mengukur kembali variabel-variabel penelitian untuk melihat konsistensi hubungan antar variabel seiring dengan berjalannya waktu.

\section{SIMPULAN DAN SARAN}

\section{Simpulan}

Penelitian ini memberikan sumbangan teori dengan membuktikan makna hidup sebagai mekanisme psikologis yang menghubungkan antara grit dan kepuasan hidup. Makna hidup secara parsial berperan sebagai mediator pada hubungan antara grit dan kepuasan hidup. 


\section{Saran Teoretis}

Hasil penelitian ini dapat memperluas teori tentang makna hidup. Akan tetapi, peran makna hidup sebagai mediator bersifat parsial. Hal ini berarti terdapat varian dari grit pada kepuasan hidup yang tidak dapat dijelaskan oleh makna hidup. Dugaan sementara dari hasil penelitian ini adalah karena data tingkat grit yang diperoleh dari sampel yang digunakan dalam penelitian ini (yaitu mahasiswa) masih sebatas kerja keras dalam pencapaian prestasi akademik, yang akan langsung dapat meningkatkan kepuasan hidup. Tingkat persistensi dan konsistensi minat yang tinggi yang ditunjukkan oleh mahasiswa belum tentu diterjemahkan sebagai memiliki makna hidup yang baik agar mereka memiliki kepuasan hidup yang tinggi. Oleh karena itu, penelitian selanjutnya dapat dilakukan dengan melakukan replikasi pada populasi yang lebih dewasa seperti pada karyawan.

\section{Saran Praktis}

Saran praktis yang dapat disarankan berdasarkan hasil penelitian ini adalah kepada pihak universitas untuk mengembangkan program yang menanamkan grit pada mahasiswa, misalnya program pelatihan yang dikhususkan untuk mahasiswa baru untuk dapat mengenali dirinya sendiri seperti: ambisi, kemampuan, dan usaha -, agar mereka dapat melakukan perencanaan tujuan jangka panjang berkelanjutan.

\section{REFERENSI}

Akbağ, M., \& Ümmet, D. (2017). Predictive role of grit and basic psychological needs satisfaction on subjective well-being for young adults. Journal of Education and Practice, 8(26), 127135.

Antaramian, S. (2017). The importance of very high life satisfaction for students' academic success. Cogent Education, 4(1), 1-10. doi: 10.1080/2331186X.2017.1307622

Baumeister, R. F. (1991). Meanings of life. New York, NY: The Guilford Press.

Behlau, S. A. (2010). Life Satisfaction: A study of undergraduate and graduate students (Tesis tidak dipublikasikan). Rowan University, Glassboro.

Borton, W., \& Grelle, J. (2013). The dirt on grit: Examining relations with school adjustment, school performance, and theories of intelligence. Hanover College. Ditemu kembali dari http://psych.hanover.edu/research/Thesis12/papers/Borton\%20Grelle\%20IS\%20Final.pdf 
Caner, A. (2015). Happiness and life satisfaction in Turkey in recent years. Social Indicators Research, 127(1), 361-399. doi: 10.1007/s11205-015-0948-z

Datu, J. A. D., King, R. B., Valdez, J. P. M., \& Eala, M. S. M. (2018). Grit is Associated with Lower Depression via Meaning in Life among Filipino High School Students. Youth \& Society (in press). https://doi.org/10.1177/0044118x18760402

Datu, J. A., Valdez, J. P., \& King, R. B. (2016). The successful life of gritty students: Grit leads to optimal educational and well-being outcomes in a collectivist context. Dalam R. King \& A. Bernardo (Eds.), The psychology of Asian learners (hlm. 503-516). Singapore: Springer.

Diener, E., Emmons, A. R., Larsen, R. J., \& Griffin, S. (1985). The satisfaction with life scale. Journal of Personality Assessment, 49(1), 71-75. doi: 10.1207/s15327752jpa4901_13

Diener, E., Scollon, C. N., \& Lucas, R. E. (2009). The evolving concept of subjective well-being: The multifaceted nature of happiness. Dalam E. Diener (Eds.), Social indicators research series: Vol. 39. Assessing well-being: The collected works of Ed Diener (hlm. 67-100). New York, NY: Springer Science and Business Media.

Diener, E., Suh, E. M., Lucas, R. E., \& Smith, H. L. (1999). Subjective well-being: Three decades of progress. Psychological Bulletin, 125(2), 276-302. doi: 10.1037/0033-2909.125.2.276

Doğan, T., Sapmaz, F., Tel, F. D., Sapmaz, S., \& Temizel, S. (2012). Meaning in life and subjective well-being among Turkish university students. Procedia - Social and Behavioral Sciences, 55, 612-617. doi: 10.1016/j.sbspro.2012.09.543

Duckworth, A. L., Peterson, C., Matthews, M. D., \& Kelly, D. R. (2007). Grit: Perseverance and passion for long-term goals. Journal of Personality and Social Psychology, 92(6), 10871101. doi: 10.1037/0022-3514.92.6.1087

Duckworth, A. L., \& Quinn, P. D. (2009). Development and validation of short grit scale (Grit-S). Journal of Personality Assesment, 91(2), 166-174. doi: 10.1080/00223890802634290

Hayes, A. F. (2013). Introduction to mediation, moderation, and conditional process analysis: A regression-based approach. New York, NY: The Guilford Press.

Hadijah, S. (2017). Ini dia alasan kenapa kuliah itu wajib untuk karir kamu! Ditemu kembali dari https://www.cermati.com/artikel/ini-dia-alasan-kenapa-kuliah-itu-wajib-untuk-karir-kamu

Herwibowo, D. (2010). Hubungan persepsi kebebasan dalam waktu luang dan subjective wellbeing pada mahasiswa Universitas Indonesia (Tesis tidak dipublikasikan). Universitas Indonesia, Indonesia. 
Hill, P. L., Burrow, A. L., \& Bronk, K. C. (2016). Persevering with positivity and purpose: An examination of purpose commitment and positive affect as predictors of grit. Journal of Happiness Studies, 17(1), 257-269.

Ho, M. Y., Cheung, F. M., \& Cheung, S. F. (2010). The role of meaning in life and optimism in promoting well-being. Personality and Individual Differences, 48(5), 658-663. doi: 10.1016/j.paid.2010.01.008

Hurlock, E. B. (2009). Psikologi perkembangan: Suatu pendekatan sepanjang rentang kehidupan. Jakarta: Erlangga.

Jin, B., \& Kim, J. (2017). Grit, basic needs satisfaction, and subjective well-being. Journal of Individual Differences, 38(1), 29-35. doi: 10.1027/1614-0001/a000219

Kaplan, R. M., \& Saccuzzo, D. P. (2001). Psychological testing: Principles, applications, and issues (5th ed.). Belmont, CA: Wadsworth.

Kleiman, E. M., Adams, L. M., Kashdan, T. B., \& Riskind, J. H. (2013). Gratitude and grit indirectly reduce risk of suicidal ideations by enhancing meaning in life: Evidence for a mediated moderation model. Journal of Research in Personality, 47(5), 539-546. doi: 10.1016/j.jrp.2013.04.007

Li, J., Fang, M., Wang, W., Sun, G., \& Cheng, Z. (2018). The influence of grit on life satisfaction: Self-esteem as a mediator. Psychologica Belgica, 58(1), 51-66. doi: 10.5334/pb.400

Lucas, R. E., Diener, E., \& Suh, E. (1996). Discriminant validity of well-being measures. Journal of Personality and Social Psychology, 71(3), 616-628. doi: 10.1037/0022-3514.71.3.616

Mahmoud, J. S., Staten, R., Hall L. A., Lennie, T. A. (2012). The relationship among young adult college students' depression, anxiety, stress, demographics, life satisfaction, and coping styles. Issues in Mental Health Nursing. 33(3), 149-56. doi: 10.3109/01612840.2011.632708

Malik, M., Nordin, N., Zakaria, A., \& Sirun, N. (2013). An exploratory study on the relationship between life satisfaction and academic performance among undergraduate students of UiTM, Shah Alam. Procedia - Social and Behavioral Sciences, 90, 334-339. doi: 10.1016/j.sbspro.2013.07.099

Niramaya, C. A. (2017). Mencapai kepuasan hidup yang lebih: Peran mediasi pikiran positif dan makna hidup dalam hubungan emosi syukur-kepuasan hidup (Skripsi tidak dipublikasikan). Universitas Indonesia, Indonesia.

Papalia, D. E., Feldman, R. D., \& Martorell, G. (2015). Experience human development (13th ed.). New York, NY: McGraw Hill Education. 
Pan, J., Wong, D. F., Joubert, L., \& Chan, C. L. (2008). The protective function of meaning of life on life satisfaction among Chinese students in Australia and Hong Kong: A cross-cultural comparative study. Journal of American College Health, 57(2), 221-232. doi: 10.3200/jach.57.2.221-232

Pavot, W., \& Diener, E. (1993). Review of the satisfaction with life scale. Psychological Assessment, 5(2), 164-172. doi: 10.1037/1040-3590.5.2.164

Podsakoff, P. M., MacKenzie, S. B., Lee, J., \& Podsakoff, N. P. (2003). Common method biases in behavioral research: A critical review of the literature and recommended remedies. Journal of Applied Psychology, 88(5), 879-903. doi: 10.1037/0021-9010.88.5.879

Rode, J. C., Arthaud-Day, M. L., Mooney, C. H., Near, J. P., Baldwin, T. T., Bommer, W. H., \& Rubin, R. S. (2005). Life satisfaction and student performance. Academy of Management Learning and Education, 4(4), 421-433. doi: 10.5465/amle.2005.19086784

Salles, A., Cohen, G. L., \& Mueller, C. M. (2014). The relationship between grit and resident wellbeing. American Journal of Surgery, 207(2), 251-254. doi: 10.1016/j.amjsurg.2013.09.006

Shin, D. C., \& Johnson, D. M. (1978). Avowed happiness as an overall assessment of the quality of life. Social Indicators Research, 5(1-4), 475-492. doi: 10.1007/bf00352944

Singh, K., \& Jha, S. D. (2008). Positive and negative affect, and grit as predictors of happiness and life satisfaction. Journal of the Indian Academy of Applied Psychology, 34(Spec Issue), 4045.

Steger, M. F., Frazier, P., Oishi, S., \& Kaler, M. (2006). The meaning in life questionnaire: Assessing the presence of and search for meaning in life. Journal of Counseling Psychology, 53(1), 80-93. doi: 10.1037/0022-0167.53.1.80

Suldo, S. M., Minch, D., \& Hearon, B. V. (2014). Adolescent life satisfaction and personality characteristics: Investigating relationships using a Five Factor Model. Journal of Happiness Studies, 16(4), 965-983. doi: 10.1007/s10902-014-9544-1

Suzuki, Y., Tamesue, D., Asahi, K., \& Ishikawa, Y. (2015). Grit and work engagement: A crosssectional study. PLOS ONE, 10(9), e0137501. doi: 10.1371/journal.pone.0137501

Yang, C., \& Srinivasan, P. (2016). Life satisfaction and the pursuit of happiness on twitter. PLOS ONE, 11(3), e0150881. doi: 10.1371/journal.pone.0150881

You, Z., Song, J., Wu, C., Qin, P., \& Zhou, Z. (2014). Effects of life satisfaction and psychache on risk for suicidal behaviour: A cross-sectional study based on data from Chinese undergraduates. BMJ Open, 4(3), e004096. doi: 10.1136/bmjopen-2013-004096 